\title{
Lung Adenosquamous Carcinoma
}

National Cancer Institute

\section{Source}

National Cancer Institute. Lung Adenosquamous Carcinoma. NCI Thesaurus. Code C9133.

An aggressive carcinoma with a poor prog nosis characterized by a presence of both malignant squamous cells and glandular cells. 